\title{
Assessment of In Vitro Antigenotoxic Effect of Nigella Sativa Oil
}

\section{Nigella Sativa Yağının In Vitro Antigenotoksik Etkisinin Değerlendirilmesi}

\author{
(1) Murat ZOR ${ }^{1 *}$, (1) Elçin Latife ASLAN2 \\ 1Lokman Hekim University, Department of Pharmacognosy, Ankara, Turkey \\ 2Lokman Hekim University, Department of Medical Biology, Ankara, Turkey
}

\begin{abstract}
Objectives: Cyclophosphamide (CP) is an alkylating agent widely used as an antineoplastic and immunosuppressive agent. The genotoxicity of CP has been studied in a variety of in vivo and in vitro systems and is routinely used as a positive control in genotoxicity tests. Traditional medicine Nigella sativa L., (N. sativa), Ranunculaceae family, especially in the Eastern Mediterranean countries, especially in many countries, and is widely used in many countries as a spice and folk medicine since the time of Dioscorides used as a plant. In this study, it was aimed to show the protective effects of $N$. sativa oil at different concentrations against the genotoxic effects of CP by micronucleus test.

Materials and Methods: For this purpose, healthy cells were treated in vitro with $\mathrm{N}$. sativa oil at concentrations of $1,5,10 \mu \mathrm{g} / \mathrm{mL}$ and $\mathrm{CP}$ as positive control for 68 hours. The micronuclei were then counted.

Results: No significant increase in micronucleus frequency was observed when the application of $N$. sativa oil at concentrations of $1,5,10 \mu g / m L$ compared with the negative control. There was a decrease in the number of micronucleus in all three concentrations $(1,5,10 \mu \mathrm{g} / \mathrm{mL}) \mathrm{compared} \mathrm{to}$ the CP group in the groups treated with N. sativa oil and CP.

Conclusion: It has been shown that $N$. sativa oil may have protective effects against genotoxicity agents in vitro. But more work is needed to understand the mechanism of the genotoxicity effects of $N$. sativa oil.
\end{abstract}

Key words: Cyclophosphamide, Nigella sativa oil, micronucleus, genotoxicity

öz

Amaç: Siklofosfamid, antineoplastik ve immünosüpresif ajan olarak yaygın olarak kullanılan alkilleyici bir ajandır. Siklofosfamid'in genotoksisitesi çeşitli in vivo ve in vitro sistemde çalışılmış ve rutin olarak genotoksisite testlerinde pozitif kontrol olarak kullanılmaktadır. Geleneksel tıp da Nigella sativa L. (N. sativa), Ranunculaceae familyasından olup günümüzde bașta Doğu Akdeniz ülkeleri olmak üzere birçok ülkede yaygın olarak yetişen ve hem baharat hem de halk ilacı olarak Dioscorides zamanından beri kullanılan bir bitkidir. Bu çalışmada Siklofosfamid'in genotoksik etkilerine karşı çörek otu yağının değişik konsantrasyonlardaki koruyucu etkilerininin mikronükleus testi ile gösterilmesi amaçlanmıştır.

Gereç ve Yöntemler: Bu amaçla, sağlıklı hücreler 1, 5, $10 \mu \mathrm{g} / \mathrm{mL}$ konsantrasyonlarında N. sativa yağı ile ve pozitif kontrol olarak Siklofosfamid ile 68 saat boyunca in vitro muamele edildi. Daha sonra ise mikronükleuslar sayıldı.

Bulgular: N. sativa yağının 1, 5, $10 \mu \mathrm{g} / \mathrm{mL}$ konsantrasyonlarındaki uygulaması negatif kontrolle karşılaştırıldığında mikronükleus frekansında anlamlı

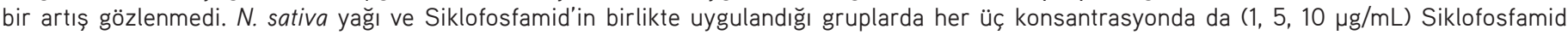
grubuna göre mikronükleus sayısında azalma olduğu görüldü.

Sonuç: N. sativa yağının genotoksisite ajanlarına karşı in vitro koruyucu etkilerinin olabileceği gösterilmiştir. N. sativa yağının genotoksisiteyi giderici etkilerinin mekanizmasının anlaşılması için daha fazla çalışmaya intiyaç vardır.

Anahtar kelimeler: Siklofosfamid, Nigella sativa yağı, mikronükleus, genotoksisite

*Correspondence: E-mail: murat.zor@lokmanhekim.edu.tr, Phone: +90 5364956596 ORCID-ID: orcid.org/0000-0001-6014-2930

Received: 18.12.2019, Accepted: 02.01.2020

-Turk J Pharm Sci, Published by Galenos Publishing House. 


\section{INTRODUCTION}

Cyclophosphamide (CP) is a oxazophosphorine derivative of nitogen mustard and is an alkylating agent commonly used as an antineoplastic and immunosuppressive agent. ${ }^{1-3}$ CP is one of the universally known anti-neoplastic drugs whose therapeutic efficacy against hematological and solid malignancies and autoimmune diseases such as rheumatoid arthritis, systemic lupus erythematosus and multiple sclerosis. ${ }^{4} \mathrm{CP}$ is used in high doses for the chemotherapy of various forms of cancer, in low doses in the treatment of autoimmune diseases, and also as an immunosuppressant after organ transplants. ${ }^{5}$ CP's chemically reactive metabolic products induce cytotoxicity by alkylating DNA and proteins. ${ }^{3}$ CP is known as human carcinogen and has an increased incidence of chromosome aberrations in lymphocytes from patients with malignant and non-malignant diseases. ${ }^{6}$ The genotoxicity of CP has been studied in a variety of in vivo and in vitro systems, mutagenic, teratogenic and carcinogenic, and is routinely used as a positive control in genotoxicity tests. ${ }^{1,6}$

Natural compounds find application in the treatment of refractory diseases, a new trend in modern clinical medicine. ${ }^{7}$ Nigella sativa ( $N$. sativa) is a short-lived annual plant of the Ranunculaceae family, known as black seed, black cumin and fennel flower. ${ }^{8,9} \mathrm{~N}$. sativa is an aromatic plant with tremendous therapeutic properties such as hypotensive, gastroprotective, nephrocurative, nephroprotective, antioxidative, antimicrobial, genoprotective, neuroprotective, immunomodulatory, antiinflammatory, hypoglycemic, hypolipidemic, anticarcinogenic and hepatoprotective. ${ }^{9,10}$ It increases the production of two substances, interferon and interleukin, the first defense shield of the immune system against tumor cells. ${ }^{11} \mathrm{~N}$. sativa seeds are very rich in fixed oil, essential fatty acids, alkaloids, phytosterols, glycolipids and phospholipids, saponins and essential oil components. In seed essential oil; thymoquinone, $p$-cymene and thymol are the active components. Thymoquinone has been shown as a cytotoxic agent in several human tumor cell lines resistant to various multidrug drugs.' It has also been shown in another study that gastric cancer cells inhibit their growth. ${ }^{12}$ The effect of high dose thymoquinone on stomach was found to be equal to Omeprazole. ${ }^{13}$ Molecular mechanisms underlying these anticancer effects; cell cycle arrest, apoptosis, oxidative damage of cellular macromolecules, blockade of tumor angiogenesis and inhibition of tumor migration. ${ }^{1}$ Micronucleus analysis methods are widely used in genotoxicity studies at chromosome level. The frequency of micronucleus formation is considered to be an indicator of damage to the genetic material. Micronuclei are those that occur during cell division, originating from centric or ascentric chromosome fragments that are not involved in the core nucleus. ${ }^{14}$

In this study, it was aimed to show the healing effects of $N$. sativa oil at different concentrations against the genotoxic effects of CP by micronucleus test.

\section{MATERIALS AND METHODS}

\section{Materials}

Micronucleus testing is usually performed in peripheral blood lymphocytes to determine genotoxicity in humans. Because in the studies performed, the increase in the micronucleus frequency in peripheral blood lymphocytes from cancer patients was found to be as much as the micronucleus frequency in the target tissue..$^{15-17}$ N. sativa oil was obtained from a local vegetable urea shop and stored in dark brown bottles until use. It was dissolved in dimethyl sulfoxide and then applied to the cells at a final concentration of 1,5 and $10 \mu \mathrm{g} / \mathrm{mL}$. CP, cytochalasine $B$, RPMI medium, phytohemaglutinin, antibiotic, fetal calf serum, L-Glutamine and Giemsa solution were obtained from Sigma.

\section{Methods}

Micronucleus test was performed according to the method described by Fenech and Morley. ${ }^{18}$ For the analysis of micronucleus in binucleated lymphocytes, cell culture was established from $0.2 \mathrm{~mL}$ of fresh heparinized blood. Cells were treated with $N$. sativa oil at a final concentration of $1 \mu \mathrm{g} / \mathrm{mL}, 5$ $\mu \mathrm{g} / \mathrm{mL}, 10 \mu \mathrm{g} / \mathrm{mL}$. Cytochalasin B was added to each tube at a final concentration of $6 \mu \mathrm{g} / \mathrm{mL}$ at 44 hours of incubation. After 24 hours of incubation at $37^{\circ} \mathrm{C}$, the cells were centrifuged and micronucleus test in peripheral lymphocytes was performed. ${ }^{18}$ Cells were harvested with hypotonic $(0.4 \% \mathrm{KCl})$ and fixative (methanol: acetic acid) solution. Cell suspensions were stained with Giemsa after dropping onto clean glass slides. CP was also used as a positive control. CP was given to the tubes at a final concentration of $0.16 \mu \mathrm{g} / \mathrm{mL}$. Micronucleus scoring was limited to binuclear lymphocytes with cytoplasm according to the criteria determined by Fenech et al. ${ }^{19}$ Two thousand binucleated lymphocytes were scored for each donor (8000 binucleated cells per concentration). ${ }^{20}$

\section{Statistical analysis}

Windows for SPSS version 22 statistical software program was used to analyze the data. Experimental and control groups were analyzed with one way Anova. Arithmetic mean $(X) \pm$ and standard deviation was determined. $P<0.05$ was considered significant.

\section{RESULTS}

Micronucleus data in cells treated with $\mathrm{CP}$ and $N$. sativa oil and both are shown in Table 1. Micronucleus frequency for the control group was determined as 3.5. CP treatment increased the micronucleus ratio to 25.2 . This value was significantly higher than the control group ( $p<0.05)$. No significant increase in micronucleus frequency was observed when the application of $N$. sativa oil at concentrations of $1,5,10 \mu \mathrm{g} / \mathrm{mL}$ compared with the negative control. There was a decrease in the number of micronucleus in all three concentrations $(1,5,10 \mu \mathrm{g} / \mathrm{mL})$ compared to the CP group in the groups treated with $N$. sativa oil and CP (Table 1). 
Table 1. Frequency of MN in cultured human lymphocytes treated with $N$. sativa oil

\begin{tabular}{lll} 
Test substance & Concentrations & MN $(X \pm S D)$ \\
\hline Control & - & $3.5 \pm 0,57$ \\
\hline Cyclophosphamide & $0.16 \mu \mathrm{g} / \mathrm{mL}$ & $25.2 \pm 3.8^{\mathrm{a}}$ \\
\hline N.sativa oil & $1 \mu \mathrm{g} / \mathrm{mL}$ & $3.5 \pm 1.29^{\mathrm{b}}$ \\
& $5 \mu \mathrm{g} / \mathrm{mL}$ & $5.25 \pm 0.95^{\mathrm{b}}$ \\
& $10 \mu \mathrm{g} / \mathrm{mL}$ & $2.75 \pm 0.95^{\mathrm{b}}$ \\
\hline Cyclophosphamide + & $0.16 \mu \mathrm{g} / \mathrm{mL}+1 \mu \mathrm{g} / \mathrm{mL}$ & $19.75 \pm 2.5^{\mathrm{ac}}$ \\
N.sativa oil & $0.16 \mu \mathrm{g} / \mathrm{mL}+5 \mu \mathrm{g} / \mathrm{mL}$ & $17.75 \pm 4.64$ \\
& $0.16 \mu \mathrm{g} / \mathrm{mL}+10 \mu \mathrm{g} / \mathrm{mL}$ & $20.5 \pm 3.55^{\mathrm{ac}}$ \\
\hline
\end{tabular}

SD: Standart deviation, $p<0.05,2000$ cells were scored for each tube, a: Significant difference from control, b: Significant difference from cyclophosphamide, ${ }^{c}$ : Significant difference from Nigella sativa oil, MN: Micronucleus

\section{DISCUSSION}

Phytotherapy is an area that uses plants as health promoting agents to treat diseases. In the conventional use of phytotherapies, the original composition of the plant or a certain percentage of certain components of the plant is generally used. ${ }^{21}$ Medicinal plants are considered to be the main source of potentially therapeutically effective new chemicals. According to the data of the World Health Organization, $70-80 \%$ of the population in developing countries relies on plants for primary health care. ${ }^{22}$ $N$. sativa oil, including the main components of thymoquinone and P-cymene, is considered to have anti-inflammatory, hepatoprotective and reno-protective effects. ${ }^{23}$ One of the most commonly used cytogenetic assays for genotoxic evaluation of different agents is Cytokinesis Blocked Micronuclei test in cultured human leukocytes. ${ }^{22}$ In this study we investigated the effect of $N$. sativa oil on genotoxicity in human leukocytes. $N$. sativa oil was used in different concentrations $(1,5,10 \mu \mathrm{g} /$ $\mathrm{mL}$ ). Unlike our study, Abdel-Moneim et al. ${ }^{24}$ investigated the protective effects of $N$. sativa seeds against genotoxicity and chromotomal aberrations induced by carbon tetrachloride in mouse spermatocytes. In our study, the therapeutic effects of $N$. sativa oil were investigated in spite of the application of CP in lymphocyte cells from healthy individuals instead of mouse spermatocytes. Abdel-Moneim et al. ${ }^{24}$ have shown that N.sativa is effective in the prevention of $\mathrm{CCl}_{4}$-induced genetic damage in germ cells and can be used as an adjunct nutritional supplement in the early stages of exposure to mutagens. Similarly, in our study, it was observed that the amount of micronucleus decreased in the group in which CP was used together with $N$. sativa oil compared to the positive control group. In the study of Galhena et al. ${ }^{25}$, a mixture of $100-600 \mu \mathrm{g} / \mathrm{mL}$ consisting of $N$. sativa seeds, Hemidesmus indicus ( $H$. indicus) roots and Smilax glabra (S. glabra) rhizomes was applied to human lymphocyte culture together with bleomycin and chromosome aberrations such as dicentric chromosome, ascentric fragment, chromatid fractures were examined. According to the results of this study; $N$. sativa seeds, $H$. indicus roots and S. glabra rhizomes showed that the mixture has the potential to protect against cytogenetic damage caused by bleomycin in human peripheral lymphocytes. In our study, $N$. sativa oil was used instead of $N$. sativa seeds and only micronucleus frequency was examined. However, when the results were examined, similar to the results of Galhena et al. ${ }^{25}$. Hashem et al. ${ }^{10}$ concluded that $N$. sativa oil is potentially protective against carbendazim-induced hematoxixity, hepatotoxicity and genotoxicity. In this study, it was determined that $N$. sativa oil moderately improved in terms of micronucleus percentage and DNA fragmentation when applied together with carbendazim and mancozeb. In our study, positive control CP was used to determine the healing effect of $N$. sativa oil and in vitro cell culture experiments were performed. Al-Okbi et al. ${ }^{23}$ investigated the effect of using $N$. sativa oil alone and in combination with fish oil in $\mathrm{CCl}_{4}$ treated rats. According to the results of this study, it was observed that combined oral administration of $N$. sativa oil and fish oil-N. sativa oil combined with anti-inflammatory and antioxidant activity reduced liver and kidney damage. Nguyen et al. ${ }^{26}$ in Morocco investigated the in vitro cytotoxicity, genotoxicity and antigenotoxicity of aqueous plant extracts from three different regions (Erfoud, Fkih ben Salah, Settat) by the neutral red uptake test in human C3A cells, the bacterial Vitotox, Ames assays, comet assay and micronucleus test. $N$. sativa seed extracts showed varying degrees of antigenotoxicity depending on where the test specimens came from. Extracts from Fkih ben Salah and Settat were reported to exhibit antigenotoxic effects by significantly reducing the micronucleus number at concentrations of 9 $\mathrm{mg} / \mathrm{mL}$. Similarly, in our study, the effects of $N$. sativa oil on micronucleus formation in healthy human lymphocyte cell culture at concentrations of 1,5 and $10 \mu \mathrm{g} / \mathrm{mL}$ were examined and the genotoxic effects of CP used as positive control were reduced by $N$. sativa oil in all three concentrations. Although $N$. sativa oil concentrations and cell type used in our study were different from those of Nguyen et al. ${ }^{26}$, similar results were found. However, the location of the samples, the test and other test conditions may affect the research result.

\section{CONCLUSION}

In this study, it was shown that N. sativa oil may have curative effects against mutation inducing agents. To understand the mechanism of the genotoxicity effects of $N$. sativa oil, molecular tests, testing of different concentrations and in vivo experiments are needed.

Conflict of Interest: No conflict of interest was declared by the authors.

\section{REFERENCES}

1. Yuksel S, Tasdemir S, Korkmaz S. Protective effect of thymoquinone against cyclophosphamide-induced genotoxic damage in human lymphocytes. Bratisl Lek Listy. 2017;118:208-211.

2. Tuorkey MJ. Therapeutic Potential of Nigella sativa Oil Against Cyclophosphamide-Induced DNA Damage and Hepatotoxicity. Nutr Cancer. 2017;69:498-504

3. Habibi E, Shokrzadeh M, Ahmadi A, Chabra A, Naghshvar F, KeshavarzMaleki R. Genoprotective effects of Origanum vulgare ethanolic extract against cyclophosphamide-induced genotoxicity in mouse bone marrow cells. Pharm Biol. 2015;53:92-97. 
4. Basu A, Bhattacharjee A, Samanta A, Bhattacharya S. Prevention of cyclophosphamide-induced hepatotoxicity and genotoxicity: Effect of an L-cysteine based oxovanadium(IV) complex on oxidative stress and DNA damage. Environ Toxicol Pharmacol. 2015;40:747-757.

5. Ince S, Kucukkurt I, Demirel HH, Acaroz DA, Akbel E, Cigerci IH. Protective effects of boron on cyclophosphamide induced lipid peroxidation and genotoxicity in rats. Chemosphere. 2014;108:197-204.

6. Doherty AT, Hayes J, Holme P, O'Donovan M. Chromosome aberration frequency in rat peripheral lymphocytes increases with repeated dosing with hexamethylphosphoramide or cyclophosphamide. Mutagenesis. 2012;27:533-539.

7. Ijaz H, Tulain UR, Qureshi J, Danish Z, Musayab S, Akhtar MF, Saleem A, Khan KK, Zaman M, Waheed I, Khan I, Abdel-Daim M. Review: Nigella sativa (Prophetic Medicine): A Review. Pak J Pharm Sci. 2017;30:229234.

8. Edizer DT, Yigit O, Cinar Z, Gul M, Kara E, Yigitcan B, Hayır D, Atas A. Protective role of intratympanic Nigella sativa oil against gentamicin induced hearing loss. Int J Pediatr Otorhinolaryngol. 2017;97:83-88.

9. Mosbah R, Djerrou Z, Mantovani A. Protective effect of Nigella sativa oil against acetamiprid induced reproductive toxicity in male rats. Drug Chem Toxicol. 2018;41:206-212.

10. Hashem MA, Mohamed WAM, Attia ESM. Assessment of protective potential of Nigella sativa oil against carbendazim- and/or mancozebinduced hematotoxicity, hepatotoxicity, and genotoxicity. Environ Sci Pollut Res Int. 2018;25:1270-1282.

11. Swamy SM, Tan BK. Cytotoxic and immunopotentiating effects of ethanolic extract of Nigella sativa L. seeds. J Ethnopharmacol. 2000;70:1-7.

12. Badary OA, Al-Shabanah OA, Nagi MN, Al-Rikabi AC, Elmazar MM. Inhibition of benzo(a)pyrene-induced forestomach carcinogenesis in mice by thymoquinone. Eur J Cancer Prev. 1999;8:435-440.

13. Magdy MA, Hanan el A, Nabila el M. Thymoquinone: Novel gastroprotective mechanisms. Eur J Pharmacol. 2012;697:126-131.

14. Norppa H, Falck GC. What do human micronuclei contain? Mutagenesis. 2003;18:221-233

15. Kirsch-Volders M, Elhajouji A, Cundari E, Van Hummelen P. The in vitro micronucleus test: a multi-endpoint assay to detect simultaneously mitotic delay, apoptosis, chromosome breakage, chromosome loss and non-disjunction. Mutat Res. 1997;392:19-30.

16. Vanparys $\mathrm{P}$, Vermeiren $\mathrm{F}$, Sysmans $\mathrm{M}$, Temmerman $\mathrm{R}$. The micronucleus assay as a test for the detection of aneugenic activity. Mutat Res. 1990;244:95-103.
17. Cheng TJ, Christiani DC, Xu X, Wain JC, Wiencke JK, Kelsey KT. Increased micronucleus frequency in lymphocytes from smokers with lung cancer. Mutat Res. 1996;349:43-50.

18. Fenech M, Morley AA. Cytokinesis-block micronucleus method in human lymphocytes: effect of in vivo aging and low dose $\mathrm{X}$ irradiation. Mutat Res.1986; 161:193-198.

19. Fenech M, Chang WP, Kirsch-Volders M, Holland N, Bonassi S, Zeiger E; HUman MicronNucleus project. HUMN project: detailed description of the scoring criteria for the cytokinesis-block micronucleus assay using isolated human lymphocyte cultures. Mutat Res. 2003;534:65-75.

20. Ionescu ME, Ciocirlan M, Becheanu G, Nicolaie T, Ditescu C, Teiusanu AG, Gologan SI, Arbanas T, Diculescu MM. Nuclear Division Index may Predict Neoplastic Colorectal Lesions. Maedica (Buchar). 2011;6:173178.

21. Falzon CC, Balabanova A. Phytotherapy: An Introduction to Herbal Medicine. Prim Care. 2017;44:217-227.

22. Milosevic-Djordjevic O, Radovic Jakovljevic M, Markovic A, Stankovic M, Ciric A, Marinkovic D, Grujičić D. Polyphenolic contents of Teucrium polium $\mathrm{L}$. and Teucrium scordium $\mathrm{L}$. associated with their protective effects against MMC-induced chromosomal damage in cultured human peripheral blood lymphocytes. Turk J Biol. 2018;42:152-162.

23. Al-Okbi SY, Mohamed DA, Hamed TE, Edris AE, Fouda K. Hepatic Regeneration and Reno-Protection by Fish oil, Nigella sativa Oil and Combined Fish Oil/Nigella sativa Volatiles in CCl4 Treated Rats. J Oleo Sci. 2018;67:345-353.

24. Abdel-Moneim AM, Essawy AE, Hamed SS, Abou-Gabal AA, Alzergy AA. Protective effect of Nigella sativa seeds against spermatocyte chromosomal aberrations and genotoxicity induced by carbon tetrachloride in mice. Environ Sci Pollut Res Int. 2017;24:11677-11682.

25. Galhena BP, Samarakoon SSR, Thabrew MI, Paul SFD, Perumal V, Mani C. Protective Effect of a Polyherbal Aqueous Extract Comprised of Nigella sativa (Seeds), Hemidesmus indicus (Roots), and Smilax glabra (Rhizome) on Bleomycin Induced Cytogenetic Damage in Human Lymphocytes. Biomed Res Int. 2017;2017:1856713.

26. Nguyen T, Talbi H, Hilali A, Anthonisse R, Maes A, Verschaeve L. In vitro toxicity, genotoxicity and antigenotoxicity of Nigella sativa extracts from different geographic locations. South African Journal of Botany. 2019;126:132-141. 